\title{
Action needed to improve equity and diversity in global eye health leadership
}

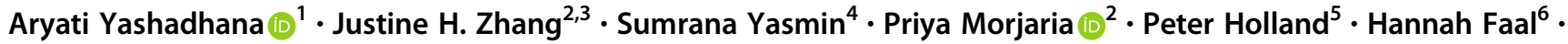 \\ Matthew J. Burton ${ }^{2,7}$ • Jacqueline Ramke $\mathbb{D}^{2,8}$
}

Received: 25 February 2020 / Accepted: 6 March 2020 / Published online: 20 March 2020

(c) The Author(s) 2020. This article is published with open access

Four out of every five people with vision loss live in lowand middle-income countries (LMIC) [1], and within all countries, good vision and eye health are not experienced equally. Eye health inequity is sustained and reproduced by interlinking factors including gender [2], ethnicity [3], and socioeconomic status [4]. Women in LMICs tend to have poorer access to eye care due to socially constructed gender norms that limit their mobility and financial decisionmaking power [5-7]. In high-income countries (HIC), services are less accessible to ethnic-minority groups $[8,9]$ and Indigenous peoples [10], and subsequently these groups are disproportionately afflicted by vision impairment and blindness $[1,3,5]$.

Organisations that are more diverse are more likely to consider otherwise marginalised perspectives, including by promoting gender and ethnic-minority focused agendas and knowledge creation [11]. Further, when more women are involved in board and senior management positions in the corporate sector, board development activities increase [12], conflict decreases [12], and social responsiveness is

Jacqueline Ramke

Jacqueline.Ramke@1shtm.ac.uk

1 School of Public Health and Community Medicine, University of New South Wales, Sydney, NSW, Australia

2 International Centre for Eye Health, London School of Hygiene \& Tropical Medicine, London, UK

3 Manchester Royal Eye Hospital, Manchester, UK

4 Sightsavers, Islamabad, Pakistan

5 International Agency for the Prevention of Blindness, London, UK

6 Department of Ophthalmology, University of Calabar, Calabar, Nigeria

7 Moorfields Eye Hospital, London, UK

8 School of Optometry and Vision Science, University of Auckland, Auckland, New Zealand stronger [13]. Thus, global eye health organisations that place women, and people from ethnic minority and LMIC backgrounds in leadership positions are likely better placed to respond to the unequal distribution of eye health and care between and within countries [14].

In common with health and development organisations more broadly, eye health providers and eye health organisations are predominantly female, but leadership roles tend to be held by men $[14,15]$. Recently, more attention has been paid to the imbalance of gender $[14,16]$ and ethnic representation [15] among health, development, and academic organisations.

To inform the ongoing Lancet Global Health Commission on Global Eye Health [17], we recently explored gender parity and ethnic diversity among leaders of the 150 member organisations comprising the International Agency for the Prevention of Blindness (IAPB), the overarching alliance for the global eye care sector. Between November 2019 and January 2020, we were able to retrieve information from the websites of 119/150 organisations. From these websites, we manually extracted all available names of the board members, chairperson, senior management staff, and chief executive officer (CEO), and where a written gender pronoun or photo was available, we assessed and manually recorded their gender and ethnic-minority status. We used validated software tools to assign gender (Gender-API, version 3.14) and ethnicity (Onolytics, 2020 version) to each person based on their name. Our manual assessment agreed with the software in $93 \%$ and $90 \%$ of cases for gender and ethnicity, respectively, and, using either method, only one person was unable to be assigned a gender and five people were not assigned ethnicity status. We acknowledge the limitation that both the software and our assessment of photographs may not have accurately determined how a person identifies; however, this limitation is unlikely to have introduced systematic bias. We calculated the proportion of position holders who were women, and in organisations based in Australasia, North America, and 
Table 1 Proportion of boards, senior management teams, chairs and CEOs of member organisations of the International Agency for the Prevention of Blindness (IAPB) who are women, 2020.

\begin{tabular}{|c|c|c|c|c|c|c|c|c|c|c|c|}
\hline \multirow[t]{2}{*}{ GBD Super-regions } & \multicolumn{3}{|c|}{ Organisations } & \multicolumn{2}{|l|}{ Board } & \multicolumn{2}{|c|}{ Senior management } & \multicolumn{2}{|l|}{ Chair } & \multicolumn{2}{|l|}{ CEO } \\
\hline & $\begin{array}{l}\text { Data } \\
\text { available } n\end{array}$ & $\begin{array}{l}\text { No data } \\
\text { available }^{\mathrm{a}} n\end{array}$ & $\begin{array}{l}\text { Indivduals } \\
\text { included } n\end{array}$ & $\begin{array}{l}\text { Female } \\
n(\%)\end{array}$ & $\begin{array}{l}\text { Total } \\
n\end{array}$ & $\begin{array}{l}\text { Female } \\
n(\%)\end{array}$ & Total $n$ & $\begin{array}{l}\text { Female } \\
n(\%)\end{array}$ & $\begin{array}{l}\text { Total } \\
n\end{array}$ & $\begin{array}{l}\text { Female } \\
n(\%)\end{array}$ & $\begin{array}{l}\text { Total } \\
n\end{array}$ \\
\hline High income $^{\mathrm{b}}$ & 85 & 12 & 1083 & $255(30.7)$ & 830 & $119(45.2)$ & 263 & $14(21.2)$ & 66 & $23(37.7)$ & 61 \\
\hline $\begin{array}{l}\text { Latin America and } \\
\text { Caribbean }\end{array}$ & 2 & 11 & 30 & $3(14.3)$ & 21 & $6(66.7)$ & 9 & 0 & 2 & 0 & 2 \\
\hline $\begin{array}{l}\text { North Africa and } \\
\text { Middle East }\end{array}$ & 4 & 2 & 30 & $6(25.0)$ & 24 & $2(33.3)$ & 6 & 0 & 6 & $1(33.3)$ & 3 \\
\hline South Asia ${ }^{c}$ & 21 & 2 & 252 & $34(18.1)$ & 188 & $8(12.5)$ & 64 & $1(7.1)$ & 14 & $3(21.4)$ & 14 \\
\hline $\begin{array}{l}\text { South-East Asia, East } \\
\text { Asia and Oceania }\end{array}$ & 3 & 4 & 29 & $11(50.0)$ & 22 & $2(28.6)$ & 7 & $1(50.0)$ & 2 & 0 & 1 \\
\hline Sub-Saharan Africa & 4 & - & 41 & $3(15.8)$ & 19 & $12(54.5)$ & 22 & 0 & 2 & $2(66.7)$ & 3 \\
\hline Total & $119^{\mathrm{d}}$ & 31 & 1465 & $312(28.3)$ & 1101 & 149 (40.9) & 364 & $16(17.8)$ & 90 & $29(34.5)$ & 84 \\
\hline
\end{tabular}

$C E O$ chief executive officer, $G B D$ global burden of disease.

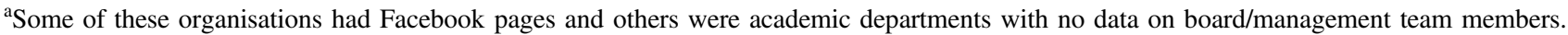

b Includes organisations from the regions: Asia Pacific, Australasia, Southern Latin America, North America and Western Europe.

${ }^{\mathrm{c}}$ Includes one person of unknown gender.

${ }^{\mathrm{d}}$ Information not available for all leadership categories across organisations.

Western Europe, the proportion of positions held by people from an ethnic minority.

Globally, fewer than one in five chairs (17.8\%) and one in three board positions $(28.3 \%)$ were held by women (Table 1). Compared with board and chair positions, women were more commonly found amongst senior management teams $(40.9 \%)$ and CEOs (34.5\%), but still not close to parity.

IAPB organisations are predominantly situated in the HIC regions of Australasia, North America and Western Europe. Countries in these regions have considerable ethnic-minority populations-for example, $40 \%$ of people in the United States [18], 34\% in New Zealand [19], 15\% in Australia [20] and 14\% in the UK [21] identify with at least one non-European ethnicity. Significant resource mobilisation for eye health occurs in these regions, allowing leaders of organisations to drive the global agenda, including distribution of funding and resources to LMICs. In these regions, gender parity was only observed amongst senior management teams in Australasia (Table 2). For all roles across all three regions, ethnic-minority women were the group holding fewest leadership positions, and North America was the only region in which they were a board chair or CEO (Table 2).

The World Report on Vision [5] highlighted the need for inclusive and participatory leadership in order to carry out strategic planning incorporating equity by design to deliver Universal Health Coverage for eye health, and to support collaboration across governments, civil society, and the private sector. We have found that women-and in particular ethnic-minority women-are under-represented in leadership positions of IAPB member organisations, and that this disparity becomes greater at higher levels of leadership. A limitation of this study was that we were unable to ascertain whether leaders of HIC organisations were from LMICs, however, our impression is that these are very few.

IAPB member organisations are lagging behind the broader health and development sector on gender parity. For example, the cohort of 140 leading health and development organisations in the initial Global Health 5050 cohort had female board chairs in $35.1 \%$ of organisations in 2019 [14] -twice as high as IAPB members (17.8\%). Promisingly, quantifying and reporting these inequalities has proved useful in creating change, as the 2019 proportion of chairs who were women in the Global Health 5050 organisations increased from $25.0 \%$ in the previous year.

The forthcoming Lancet Global Health Commission on Global Eye Health [17] will include this and other examples to highlight the need for radical action in the coming decade. Action is needed to promote and support the progression of women and people from ethnic-minority backgrounds to obtain eye health leadership positions. Increasing and sustaining this diversity is most likely if organisational efforts are embedded within a larger system -akin to Global Health 5050-that supports and monitors progress towards diversity goals [22, 23]. In 2018, IAPB established a Gender Equity Working Group to exchange good gender-responsive practices among members. More recently, the group has invited IAPB members to undertake the Global Health 5050 self-assessment, with a view to creating targets which could then be monitored, ideally alongside some form of organisational accountability for change [22]. 
Table 2 Board members, senior management teams, chairs and CEOs of $75^{\mathrm{a}}$ member organisations of the International Agency for the Prevention of Blindness (IAPB) in Australasia, North America and Western Europe disaggregated by gender and ethnic minority status, 2020.

\begin{tabular}{|c|c|c|c|c|c|c|c|c|}
\hline \multirow[t]{2}{*}{ Region } & \multicolumn{2}{|c|}{$\begin{array}{l}\text { Non-ethnic } \\
\text { minority men }\end{array}$} & \multicolumn{2}{|c|}{$\begin{array}{l}\text { Ethnic } \\
\text { minority men }\end{array}$} & \multicolumn{2}{|c|}{$\begin{array}{l}\text { Non-ethnic } \\
\text { minority women }\end{array}$} & \multicolumn{2}{|c|}{$\begin{array}{l}\text { Ethnic } \\
\text { minority women }\end{array}$} \\
\hline & $n$ & Row \% & $n$ & Row \% & $n$ & Row \% & $n$ & Row \% \\
\hline \multicolumn{9}{|l|}{ Australasia } \\
\hline Chair & 5 & 62.5 & 0 & 0.0 & 3 & 37.5 & 0 & 0.0 \\
\hline CEO & 5 & 55.6 & 0 & 0.0 & 4 & 44.4 & 0 & 0.0 \\
\hline Board & 47 & 49.5 & 9 & 9.5 & 32 & 33.7 & 7 & 7.4 \\
\hline Senior management & 9 & 40.9 & 1 & 4.5 & 11 & 50.0 & 1 & 4.5 \\
\hline \multicolumn{9}{|l|}{ North America } \\
\hline Chair & 18 & 66.7 & 4 & 14.8 & 3 & 11.1 & 2 & 7.4 \\
\hline $\mathrm{CEO}$ & 13 & 50.0 & 4 & 15.4 & 7 & 26.9 & 2 & 7.4 \\
\hline Board $^{\text {b }}$ & 229 & 50.6 & 88 & 19.4 & 92 & 20.3 & 42 & 9.3 \\
\hline Senior management ${ }^{\mathrm{c}}$ & 43 & 35.8 & 18 & 15.0 & 43 & 35.8 & 15 & 12.5 \\
\hline \multicolumn{9}{|l|}{ Western Europe } \\
\hline Chair & 18 & 81.8 & 1 & 4.5 & 3 & 13.6 & 0 & 0.0 \\
\hline CEO & 12 & 54.5 & 2 & 9.1 & 8 & 36.4 & 0 & 0.0 \\
\hline Board $^{d}$ & 144 & 62.3 & 13 & 5.6 & 61 & 26.4 & 10 & 4.3 \\
\hline Senior management & 34 & 41.0 & 11 & 13.3 & 33 & 39.8 & 5 & 6.0 \\
\hline \multicolumn{9}{|l|}{ All three regions } \\
\hline Chair & 41 & 71.9 & 5 & 8.8 & 9 & 15.8 & 2 & 3.5 \\
\hline $\mathrm{CEO}$ & 30 & 52.6 & 6 & 10.5 & 19 & 33.3 & 2 & 3.5 \\
\hline Board & 420 & 53.9 & 110 & 14.1 & 185 & 23.7 & 59 & 7.6 \\
\hline Senior management & 86 & 38.2 & 30 & 13.3 & 87 & 38.7 & 21 & 9.3 \\
\hline
\end{tabular}

Beyond gender, given that many HIC organisations are primarily focused on work in LMICs, and may have significant influence on policy and funding decisions, we believe there is also a place for proactive recruitment of more internationally diverse boards with better LMIC representation. In tackling the structural barriers facing women, ethnic-minorities, and people from LMICs in these ways, global eye health organisations will be better placed to reduce the pervasive inequity in eye health.

Funding MJB is supported by the Wellcome Trust (207472/Z/17/Z). JR is a Commonwealth Rutherford Fellow, funded by the UK government through the Commonwealth Scholarship Commission in the UK. The Lancet Global Health Commission on Global Eye Health is supported by The Queen Elizabeth Diamond Jubilee Trust, Moorfields Eye Charity [grant number GR001061], NIHR Moorfields Biomedical Research Centre, Wellcome Trust, Sightsavers, The Fred Hollows Foundation, The SEVA Foundation, British Council for the Prevention of Blindness and Christoffel Blind Mission.

\section{Compliance with ethical standards}

Conflict of interest The authors declare that they have no conflict of interest.
Publisher's note Springer Nature remains neutral with regard to jurisdictional claims in published maps and institutional affiliations.

Open Access This article is licensed under a Creative Commons Attribution 4.0 International License, which permits use, sharing, adaptation, distribution and reproduction in any medium or format, as long as you give appropriate credit to the original author(s) and the source, provide a link to the Creative Commons license, and indicate if changes were made. The images or other third party material in this article are included in the article's Creative Commons license, unless indicated otherwise in a credit line to the material. If material is not included in the article's Creative Commons license and your intended use is not permitted by statutory regulation or exceeds the permitted use, you will need to obtain permission directly from the copyright holder. To view a copy of this license, visit http://creativecommons. org/licenses/by/4.0/.

\section{References}

1. Bourne RRA, Flaxman SR, Braithwaite T, Cicinelli MV, Das A, Jonas JB, et al. Magnitude, temporal trends, and projections of the global prevalence of blindness and distance and near vision impairment: a systematic review and meta-analysis. Lancet Glob Health. 2017;5:e888-e97. 
2. Ramke J, Zwi AB, Lee AC, Blignault I, Gilbert CE. Inequality in cataract blindness and services: moving beyond unidimensional analyses of social position. Br J Ophthalmol. 2017;101:395-400.

3. Taylor HR, Boudville AI, Anjou MD, McNeil RJ. The roadmap to close the gap for vision (full report). Report no.: 978073404756 4. Melbourne: Melbourne School of Population Health, University of Melbourne; 2012.

4. Yan W, Wang W, van Wijngaarden P, Mueller A, He M. Longitudinal changes in global cataract surgery rate inequality and associations with socioeconomic indices. Clin Exp Ophthalmol. 2019;47:453-60.

5. World Health Organization. World report on vision. World Health Organization; Geneva, 2019.

6. Ibrahim N, Pozo-Martin F, Gilbert C. Direct non-medical costs double the total direct costs to patients undergoing cataract surgery in Zamfara state, Northern Nigeria: a case series. BMC Health Serv Res. 2015;15:163.

7. Mganga H, Lewallen S, Courtright P. Overcoming gender inequity in prevention of blindness and visual impairment in Africa. Middle East Afr J Ophthalmol. 2011;18:98.

8. Morales LS, Varma R, Paz SH, Lai MY, Mazhar K, Andersen RM, et al. Self-reported use of eye care among latinos: the Los Angeles latino eye study. Ophthalmology 2010;117:207-15.e1.

9. Owsley C, McGwin G, Scilley K, Girkin CA, Phillips JM, Searcey K. Perceived barriers to care and attitudes about vision and eye care: focus groups with older African Americans and eye care providers. Investig Ophthalmol Vis Sci. 2006;47:2797-802.

10. Yashadhana A, Fields T, Blitner G, Stanley R, Zwi AB. Trust, culture and communication: determinants of eye health and care among Indigenous people with diabetes in Australia. BMJ Global Health. 2020;5:e001999. https://doi.org/10.1136/bmjgh-2019-001999.

11. Sugimoto CR, Ahn Y-Y, Smith E, Macaluso B, Larivière V. Factors affecting sex-related reporting in medical research: a cross-disciplinary bibliometric analysis. Lancet 2019;393:550-9.
12. Nielsen S, Huse M. The contribution of women on boards of directors: going beyond the Surface. Corp Gov: Int Rev. 2010;18:136-48.

13. Galbreath J. Are there gender-related influences on corporate sustainability? A study of women on boards of directors. J Manag Organ. 2011;17:17-38.

14. Global Health 50/50. Global Health 50/50 2019 Report. 2019.

15. Khan MS, Lakha F, Tan MMJ, Singh SR, Quek RYC, Han E, et al. More talk than action: gender and ethnic diversity in leading public health universities. Lancet 2019;393:594-600.

16. George AS, Amin A, GarcÍa-Moreno C, Sen G. Gender equality and health: laying the foundations for change. Lancet 2019;393:2369-71.

17. Burton MJ, Faal HB, Ramke J, Ravilla T, Holland P, Wang N, et al. Announcing the Lancet Global Health Commission on Global Eye Health. Lancet Glob Health. 2019;7:e1612-e3.

18. United States Census Bureau. QuickFacts statistics: White alone, not Hispanic or Latino, percent. 2019. https://www.census.gov/ quickfacts/fact/table/US\#.

19. Stats NZ Tatauranga Aotearoa. 2013 census quickstats about culture and identity. Wellington, New Zealand: Statistics New Zealand; 2014. www.stats.govt.nz.

20. Australian Bureau of Statistics. Census of population and housing: cultural diversity in Australia 2016. 2016. https://www.abs.gov. au/ausstats/abs@.nsf/Lookup/by+Subject/2071.0 2016 Main + Features $\sim$ Cultural+Diversity+Article $\sim 60$.

21. Office for National Statistics. 2011 United Kingdom Census. 2011. https://www.ons.gov.uk/census/2011census/.

22. Kang SK, Kaplan S. Working toward gender diversity and inclusion in medicine: myths and solutions. Lancet 2019; 393:579-86.

23. Dobbin F, Schrage D, Kalev A. Rage against the iron cage: the varied effects of bureaucratic personnel reforms on diversity. Am Sociological Rev. 2015;80:1014-44. 